Article abstract-Clinical and neuropathologic evidence points to the development of Alzheimer's disease (AD) in seven Down's syndrome patients above age 40. Dementia was observed in these patients over periods of 2.5 to 9.2 years. The first clinical sign of $A D$, visual memory loss, was succeeded by impaired learning capacity and decreased occupational and social functioning, and culminated in seizures and urinary incontinence. The morphometric observations of the brains of these seven patients with AD showed that the numbers of plaques and tangles exceeded 20 per $1.5 \times 10^{6} \mu \mathrm{m}^{2}$ area, in both the prefrontal and hippocampal cortices. Plaques and tangles were also evident in the basal ganglia, thalamus, hypothalamus, and midbrain. In addition, we found that four of the seven brains showed small strokes, and five of the seven amyloid angiopathy. This study also indicates that by longitudinal neuropsychological evaluations and lab tests, which exclude other causes of dementia, the diagnosis of AD can be made even in severely and profoundly retarded patients.

NEUROLOGY 1985;35:957-961

\title{
Alzheimer's disease in Down's syndrome: Clinicopathologic studies
}

\author{
K.E. Wisniewski, MD, PhD; A.J. Dalton, PhD; D.R. Crapper McLachlan, MD; G.Y. Wen, PhD; \\ and H.M. Wisniewski, MD, PhD
}

Alzheimer's disease $(\mathrm{AD})$ neuropathology appears in Down's syndrome (DS) brains in nearly all cases studied, who were beyond age 30 or 40 at autopsy..$^{1-7}$ However, it is not clear whether DS patients manifesting Alzheimer pathology also show clinical manifestations of AD.

Clinical documentation of $\mathrm{AD}$ in $\mathrm{DS}$ patients has been made largely by retrospective studies. Moreover, the patients studied who were often institutionalized with profound mental retardation, provided conflicting information in that estimates of $\mathrm{AD}$ changes varied from $15 \%{ }^{\gamma}$ to $27 \% \%^{9.11}$ to $100 \% .^{11}$ In a prospective study ${ }^{12}$ covering 10 years, clinical evidence of AD was seen in 12 of 49 DS patients above age 40 years $(24 \%)$.

We now provide a clinicopathologic description of seven patients with DS with documented clinical manifestations of Alzheimer's dementia extending from 2.5 to 9.2 years before death.

Materials and methods. Clinical methods. Cognitive functions, defined as learning capacities and memory functions, were assessed quantitatively on a repeated, follow-up basis for five of the seven patients, using methods developed previously. $1 \cdots-1 \%$ To minimize the effects of environmental (test) conditions, each patient was examined with the same test materials under conditions as nearly identical as possible in a specially equipped mobile laboratory. To rule out causes of memory and learning incapacities unrelated to Alzheimer's disease, control studies were performed with different patients and examiners. ${ }^{14.15}$ Neurologic examination for focal and frontal release signs were conducted by D.R. Crapper McLachlan. Other clinical data used to estimate "overall regression" were obtained from personal reports by staff and from medical records. Neurologic examinations were conducted on an irregular basis two or three times before death. Cognitive assessments were conducted between two and six times, at approximately $1 / 3$-year intervals.

Criteria for inclusion in the study (excluding patient 5) were normal birth record, no prior recorded history of seizures, no gross sensory or motor impairment, and no evidence of focal neurologic signs.

Gross and microscopic neuropathologic methods. Each brain was fixed in $10 \%$ formalin and examined 6 to 8 weeks later. The brain weight was taken after fixation. Coronal slices were cut, and samples were taken from the prefrontal, hippocampal, parietal, and occipital cortices; basal ganglia, midbrain, pons, medulla, and cerebellum; and cervical, thoracic, and lumbar spinal cord. After paraffin embedding, tissues were sectioned at 8 to $10 \mu \mathrm{m}$, stained with hematoxylin-eosin and Bielschowsky's stain, and examined microscopically.

Morphometric methods. Sections from the hippocampal complex and prefrontal cortex were studied in detail. Hippocampal sections were taken without respect to the side or rostral-caudal location. Senile plaques and neurofibrillary tangles located in three different $10 \times 10$ light microscopic fields $\left(1.5 \times 10^{6} \mu \mathrm{m}^{2}\right)$ of the same section of cortex were examined and traced

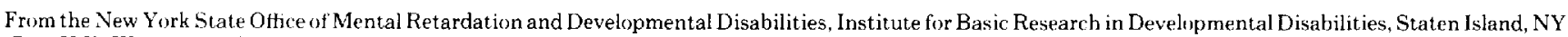

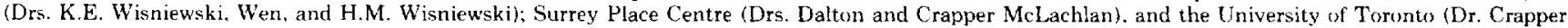
McLachlan). Toronto, Ontario, Canada.

Accepted for publication October 18. 1984.

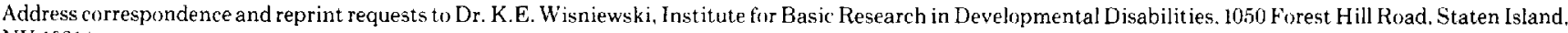
NY 10314. 
onto paper. The paper tracings were then placed on a digitizer tablet of a Zeiss computerized image analyzer (Videoplan, Carl Zeiss, New York), and the area of the $10 \times 10$ light microscope field was calculated to be $1.5 \times$ $10^{6} \mu \mathrm{m}^{2}$. The number of senile plaques and tangles per 10 $\times 10$ field of cortex was converted into densities of senile plaques and neurofibrillary tangles per $\mu \mathrm{m}^{2}$.

Results. Clinical studies. A summary of clinical findings is found in table 1 . The average age at which signs of cognitive deficits of $A D$ appeared was $51.0 \pm 6.2$ years (ranging from 43.2 years in patient 1 to 57.6 years in patient 6). The average duration of cognitive deficits, behavioral changes, and social and occupational impairments from onset to death was $5.6 \pm 2.2$ years, with death occurring between 47.2 and 65.3 years (mean, 56.6 \pm 6.5 ).

The clinical diagnosis of DS was based on clinical criteria and karyotyping. Signs of "overall regression" were recorded in six of the seven patients. The duration of clinical signs of progressive dementia had an average duration of $5.9 \pm 2.4$ years, ranging from 2.5 to 9.2 years. Frontal release signs were documented at an average of 2.6 years (range, 1.2 to 4.2 years) before death. However, examinations were sometimes spaced too far apart to yield complete data. Patient 5 died too soon after the examination, and no neurologic data were available before death. Incontinence was recorded 0.33 years to 3.5 years before death, with an average duration of 1.8 years. Seizures were reported for the first time from less than 1 month and, in some patients, as long as 3.2 years before death (mean, $1.5 \pm 1.4$ years). Progressive slow-wave EEG abnormalities were seen in five patients $(1,2,3,6$, and 7$)$. In patients 4 and 5, EEG was not performed. CT was performed only in two of seven patients ( 1 and 4 ) and showed brain atrophy. Examples of clinical signs and abnormalities are summarized in figure 1, patient 1 .

Gross neuropathologic studies. Summary of these find- ings is found in table 2. Brain weights ranged from 800 to 1,100 grams (mean, 1,032 grams). All brains were atrophied, with hydrocephalus ex vacuo and flattening of the occiput. The leptomeninges all showed thickness, and two of the seven brains had small cerebral infarcts in the area of the middle cerebral artery. Patient 4 showed an old vascular lesion involving part of the right superior middle temporal gyrus and the inferior frontal gyrus, as well as part of the basal ganglia. Patient 5 had a small subacute hematoma in the left temporal and parietal lobes. The brainstem, cerebellum, and spinal cord were grossly normal except for a small degree of atrophy.

Microscopic neuropathologic studies. All seven brains showed widespread neuronal loss and mild gliosis. Increased lipofuscin pigment in surviving nerve cells was common in the entire CNS gray matter. Granulovacuolar degeneration was detected in the hippocampal cortices of six patients. Plaques and tangles were observed, in decreasing order of severity, in the cortical mantle, basal ganglia, thalamus, hypothalamus, and midbrain.

All seven DS brains showed plaques, either scattered throughout all the cortical layers or only in the superficial layers. The neurofibrillary tangles were more visible in the granular cell layers and, to a greater extent, in the prefrontal and hippocampal cortices, the archipallium, and the amygdaloid nuclear complex. Subcortical plaques and tangles tended to be within given nucleus and tracts. Among the basal ganglia, the claustrum had only plaques, with a higher concentration in its ventral part. Plaques were seen in the vicinity of the extreme and external capsules, the inferior occipitofrontal fascicles, and the posterior limb of the internal capsules, as well as in thalamic pedunculi, thalamic fascicle, ansa and fasciculus lenticularis, and thalamic and pallidal medullary laminae. The striatum had fewer plaques than the cortex or the claustrum, and no tangles. Plaques were rare in the globus pallidus, but here some vessel walls were calcified. Tangles and

\section{Table 1. Summary of clinical findings on seven Down's syndrome patients with Alzheimer's dementia}

\begin{tabular}{|c|c|c|c|c|c|c|c|c|c|}
\hline \multirow[b]{2}{*}{ No. } & \multirow[b]{2}{*}{$\begin{array}{c}\mathbf{P t} \\
\text { sex }\end{array}$} & \multirow[b]{2}{*}{$\begin{array}{l}\text { Level of } \\
\text { retardation }\end{array}$} & \multirow[b]{2}{*}{$\begin{array}{c}\text { Age at } \\
\text { onset of AD }\end{array}$} & \multirow[b]{2}{*}{ Death } & \multicolumn{5}{|c|}{ No. of years prior to death } \\
\hline & & & & & $\begin{array}{c}\text { Cognitive } \\
\text { deficits }\end{array}$ & $\begin{array}{c}\text { Overall } \\
\text { regression }\end{array}$ & $\begin{array}{l}\text { Frontal } \\
\text { release }\end{array}$ & Incontinence & Seizures \\
\hline 1 & $\mathbf{M}$ & Severe & 43.2 & 47.2 & 4.0 & 4.0 & 3.2 & 3.5 & 2.6 \\
\hline 2 & M & Severe & 43.4 & 49.9 & 6.5 & 6.5 & 4.2 & 0.33 & 0.1 \\
\hline 3 & $\mathbf{M}$ & Severe & 52.0 & 54.5 & $\begin{array}{l}\text { Not } \\
\text { testable }\end{array}$ & 2.5 & 3.2 & 1.8 & 3.2 \\
\hline 4 & $\mathrm{M}$ & Severe & 53.7 & 57.6 & 3.9 & 7.6 & 1.5 & $\begin{array}{l}\text { Not } \\
\text { reported }\end{array}$ & 2.3 \\
\hline 5 & M & Severe & $\begin{array}{l}\text { Not } \\
\text { known }\end{array}$ & 59.5 & $\begin{array}{l}\text { Failed } \\
\text { to learn }\end{array}$ & $\begin{array}{l}\text { Not } \\
\text { reported }\end{array}$ & $\begin{array}{l}\text { Not } \\
\text { reported }\end{array}$ & $\begin{array}{l}\text { Not } \\
\text { reported }\end{array}$ & $\begin{array}{l}\text { Not } \\
\text { reported }\end{array}$ \\
\hline 6 & M & Profound & 57.6 & 62.2 & 4.5 & 5.4 & 1.5 & 1.6 & 0.3 \\
\hline 7 & $\mathrm{~F}$ & Severe & 56.1 & 65.3 & 9.2 & 9.2 & 2.0 & $\begin{array}{l}\text { Not } \\
\text { reported }\end{array}$ & 0.2 \\
\hline \multicolumn{2}{|c|}{ Means } & & $\begin{array}{l}51.0 \\
\pm 6.2\end{array}$ & $\begin{array}{l}56.6 \\
\pm 6.5\end{array}$ & $\begin{array}{l}5.6 \\
\pm 2.2\end{array}$ & $\begin{array}{l}5.9 \\
\pm 2.4\end{array}$ & $\begin{array}{l}2.6 \\
\pm 1.1\end{array}$ & $\begin{array}{l}1.8 \\
\pm 1.3\end{array}$ & $\begin{array}{l}1.5 \\
\pm 1.4\end{array}$ \\
\hline
\end{tabular}




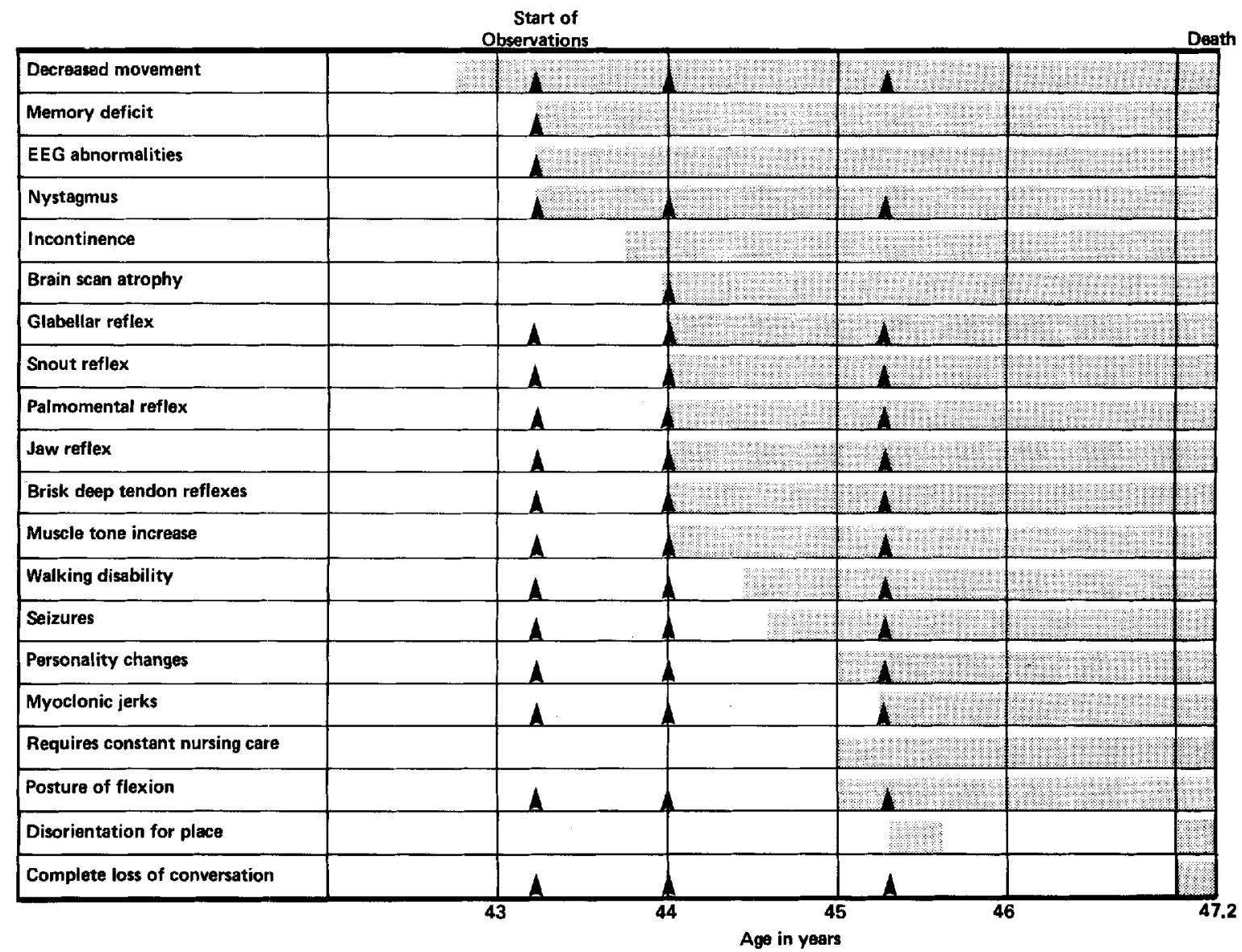

Figure 1. Patient 1. Course of Alzheimer's disease in a man with Down's syndrome who died at age 47.2 years. Arrowheads indicate direct observations and measurements. Data on incontinence, nursing requirements, and disorientation for place were based on reports from direct care staff.

plaques were observed in the anterior, paracentral, and centromedial thalamic nuclei, but less in other thalamic nuclei. In addition, the nuclei of the anterior, middle, and posterior hypothalamus; septal nuclei; nuclei basalis Meynerti; and nuclei innominati had plaques and tangles.

In all seven patients, plaques were seen in the periaqueductal gray matter and lamina quadrigemina of the midbrain. Few tangles were detected in the supratrochlear and raphe nuclei; the pons, medulla, cerebellum, and spinal cord were largely unaffected. Amyloid angiopathy was observed in five of the sever patients $(1,4$ to 7$)$. Small infarcts were detected in four of the seven DS brains $(1,4$ to 6) and were mostly localized in the hippocampal cortices and/or the basal ganglia.

The density of plaques and tangles is summarized in table 3. The density of plaques per $\mathrm{mm}^{2}$ area of the prefrontal cortex ranged from 15.3 to $\mathbf{4 0 . 3}$ (mean, 27.7 \pm 9.1 ) (figures 2 and 3 ); the tangle density ranged from 6.7 to 32.5 (mean, $18.1 \pm 10.4$ ). The density of plaques in the hippocampal cortices was 10.3 to 52.2 (mean, $27 \pm$ 17.6), and that of tangles was 19.3 to 54 (mean, $29.4 \pm$ 13.4).

The mean values and standard deviations of the densities of plaques and tangles were obtained by a
Table 2. Gross neuropathologic findings in seven Down's syndrome brains

\begin{tabular}{|ccccc|}
\hline No. & BW & Atrophy & $\begin{array}{c}\text { Hydrocephaly } \\
\text { exvacuo }\end{array}$ & CVA \\
1 & 1,030 & + & + & 0 \\
2 & 1,080 & + & + & 0 \\
3 & 1,020 & + & + & 0 \\
4 & 1,100 & + & + & + \\
5 & 1,100 & + & + & + \\
6 & 1,100 & + & + & 0 \\
7 & 800 & + & + & 0 \\
Mean $1,032 \pm 108$ & & & & \\
\hline
\end{tabular}

counting technique similar to that described by Ropper and Williams.

Discussion. Dementia is defined by loss of intellectual functioning severe enough to interfere with social functioning. ${ }^{19}$ Diagnosis of dementia is particularly difficult in DS or other mentally retarded patients who already function at the low level of the cognitive, occupational, and social scales. Since the common manifestation of $\mathrm{AD}^{20,21}$ cannot be well documented in DS patients, 
Table 3. Plaque and tangle densities per $\mathrm{mm}^{2}$ in prefrontal and hippocampal cortices of Down's syndrome patients $(\mathbf{N}=\mathbf{7})$

\begin{tabular}{|c|c|c|c|c|c|}
\hline \multirow[b]{2}{*}{ Pt. } & \multirow{2}{*}{$\begin{array}{l}\text { Ages of } \\
\text { patients }\end{array}$} & \multicolumn{2}{|c|}{ Plaques $/ \mathrm{mm}^{2}($ Mean $\pm \mathrm{SD})$} & \multicolumn{2}{|c|}{ Tangles $/ \mathbf{m m}^{2}($ Mean \pm SD $)$} \\
\hline & & Prefrontal & Hippocampal & Prefrontal & Hippocampal \\
\hline 1 & 47 & $30.3 \pm 11$ & $15.6 \pm 2.5$ & $20.0 \pm 2$ & $19.3 \pm 9.2$ \\
\hline 2 & 49 & $40.3 \pm 12.6$ & $19.6 \pm 11.5$ & $32.5 \pm 12.5$ & $54.0 \pm 12.7$ \\
\hline 3 & 54 & $15.3 \pm 4.7$ & $18.3 \pm 4.2$ & $8.3 \pm 2.3$ & $31.0 \pm 7.2$ \\
\hline 4 & 57 & $35.0 \pm 5$ & $52.3 \pm 12.5$ & $18.3 \pm 6.5$ & $39.3 \pm 10.3$ \\
\hline 5 & 59 & $17.6 \pm 4$ & $10.3 \pm 5.7$ & $6.7 \pm 3.5$ & $25.0 \pm 2$ \\
\hline 6 & 61 & $31.3 \pm 2.1$ & $20.7 \pm 6$ & $30.6 \pm 7.8$ & $19.6 \pm 8.1$ \\
\hline 7 & 65 & $24.4 \pm 5.8$ & $52.2 \pm 9.2$ & $10.5 \pm 3.9$ & $17.7 \pm 7.7$ \\
\hline \multicolumn{2}{|c|}{ Mean $\pm \mathrm{SD}$} & $27.7 \pm 9.1$ & $27.0 \pm 17.6$ & $18.1 \pm 10.4$ & $29.4 \pm 13.4$ \\
\hline
\end{tabular}

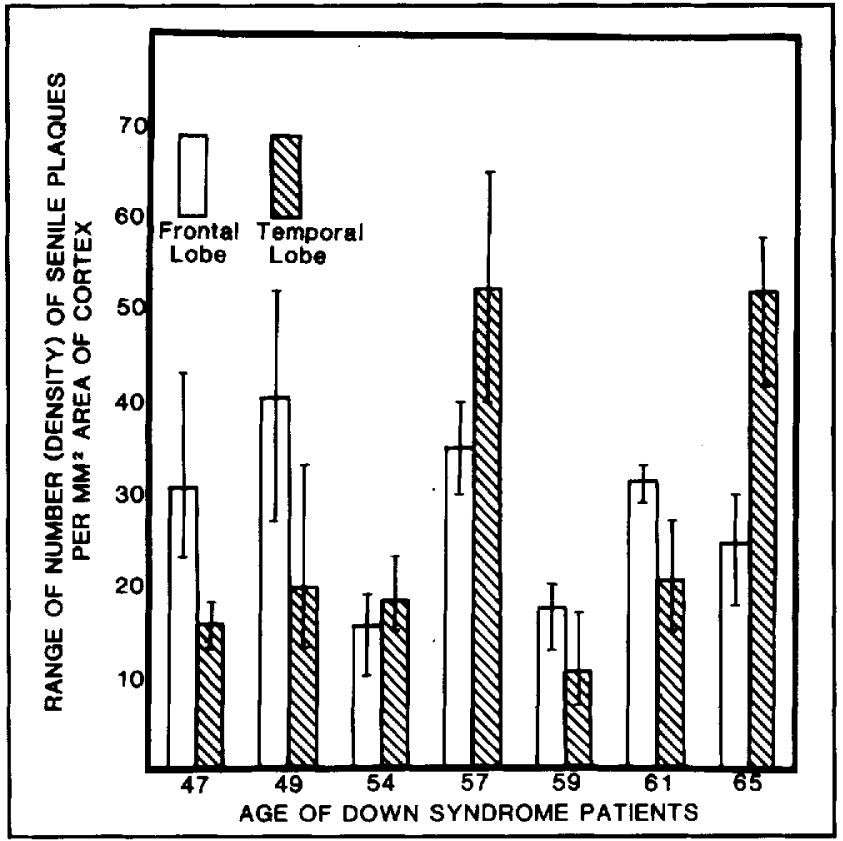

Figure 2. Numbers or density of senile plaques per $\mathrm{mm}^{2}$ area of frontal and temporal cortex of seven Down's syndrome patients with clinical presentation of Alzheimer's disease.

other criteria must also be used by the family, caretakers, or examiners to demonstrate the presence of AD. Visual memory loss, impairment of learning capacity, and behavioral changes were the initial symptoms, marking the first stage of $\mathrm{AD}$ in $\mathrm{DS}$ patients. ${ }^{18-21}$ In all six DS patients, except patient 5 , we used special tests, which were identified as such (table 1). The second stage of $\mathrm{AD}$ was marked by loss of language, comprehension with total loss of communication, impairment of social adaptive skills, episodic bouts of irritability, further personality changes, and often loss of personal hygiene. This stage is more easily detected in mentally retarded patients. The third stage of the disease can be recognized in severely retarded DS patients by mutism, poor sleep, urinary incontinence, seizures, and often the inability to walk. Focal cerebral signs appeared after stroke in two of our seven patients and were observed only in the advanced stages of $A D$. The presence of frontal release signs was documented in six of our seven DS

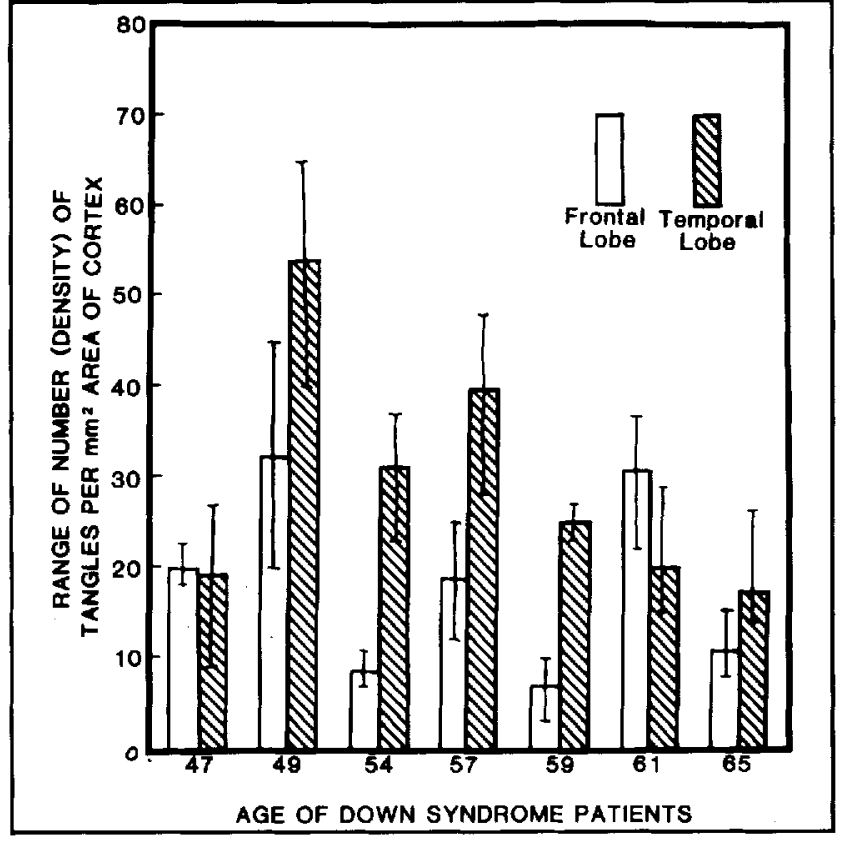

Figure 3. Number or density of neurofibrillary tangles per $\mathrm{mm}^{2}$ area of frontal and temporal cortex of seven Down's syndrome patients with clinical presentation of Alzheimer's disease.

patients. These observations have been described before. ${ }^{22}$ Brain atrophy in DS patients is known to occur before age 30 , and in $A D$, it is progressive, as it is in many neurodegenerative processes. ${ }^{10,23-27} \mathrm{CT}$ performed on $\mathrm{DS}$ patients with $\mathrm{AD}$ showed brain atrophy, ${ }^{2 / 3}$ and postmortem studies of brains of such patients also showed it to be a common phenomenon. ${ }^{10}$ EEG done in patients $1,2,3,6$, and 7 showed slowing of background activity, which is often seen in neurodegenerative diseases and is always progressive in character. ${ }^{13}$ EEG and CT changes seem to be less specific than positron emission tomography (PET) using F-2-deoxy-2fluoro-D-glucose technique. The latter showed high correlation between the degree of dementia and the reduction in regional glucose metabolism.

Our most recent neuropathologic observations involve the presence of plaques and tangles in the basal ganglia, thalamus, hypothalamus, and midbrain of all seven DS patients; and, by morphometric studies, the 
presence of more than 20 plaques (or plaques and tangles) per $1.5 \times 10^{6} \mu \mathrm{m}^{2}$. Riudelli et $\mathrm{al}^{28}$ found similar changes in the basal ganglia in non-DS Alzheimer brains. The presence of plaques and tangles in the midbrain was mainly in areas where visual and auditory connections are located. It appears that the density of plaques and tangles in brains of DS patients with a clinical diagnosis of $\mathrm{AD}$ approximates 20 to 30 plaques per $1.5 \times 10^{6} \mu \mathrm{m}^{2}$ area of cortex. The number of plaques seems to be the same in both the prefrontal and hippocampal cortices, whereas the number of tangles appears greater in the hippocampal than in the prefrontal cortex. ${ }^{810}$ Presence of cerebrovascular lesions and amyloid angiopathy was a common finding in our DS patients. These changes have been observed previously, ${ }^{29}$ but only in the non-DS brains.

As indicated above, all of our seven DS patients were severely or profoundly retarded. In spite of this, however, we were able to show-with the psychological and neurologic assessments and special tests used-the impairment of learning capacity, visual memory loss, and decrease of occupational and social functioning. All these signs and symptoms are found in Alzheimer's dementia in nonretarded people. It is generally accepted that clinical diagnosis of Alzheimer's dementia is made on the basis of excluding other causes of dementia, and the only reliable test of $\mathrm{AD}$ is clinical neuropathologic study. In summary, it appears from our studies that by longitudinal neurologic, psychological, and lab data evaluations it is possible to diagnose $\mathrm{AD}$ clinically even in severe and profound DS people. In our study we had found evidence of Alzheimer's disease in Down's syndrome patients by (1) recognition of loss of cognitive function, and (2) neuropathologic study-not only through routine analysis, but by morphometric study.

\section{Acknowledgments}

The authors gratefully acknowledge the generous assistance of Dr. Elsie Crawford for obtaining brain tissues, Dr. Catherine Bergeron of the Canadian Brain Tissue Bank for neuropathologic diagnostic assistance, and Ms. Lou Weyer of the University of Toronto Neuropathology Department for preparing the slides. Thanks are also extended to the following persons who helped in the examination of patients and collection of cognitive test performances: Maureen Bergsenbrugge, Ernest Hoffman, Arnold Lupmanis, George R. Schlotterer, and Peter Waind. We also thank Lawrence Black for editorial assistance, Richard Weed and Lucille Donadio for technical assistance, and Patricia Codoner for preparation of the manuscript.

\section{References}

1. Struwe F. Histopathology Unterschungen über Enstehung und Wesen der senilen Plaques. Z Ges Neurol Psychiat 1929:122:291-307.

2. Jervis GA. Early senile dementia in mongoloid idiocy. Am J Psych 1948; 105:102-6.

3. Solitare GB, Lamarche JB. Alzheimer's disease and senile dementia as seen in mongoloids: neuropathological observations. Am J Ment Defic 1966;70:840-8

4. Ellis WG, McCulloch JR, Corley CL. Presenile dementia in Down's syndrome ultrastructural identity with Alzheimer's dis. ease. Neurology (Minneap) 1974;24:101-6.

5. Malamud N. Neuropathology. In: Stevens HA, Heber R, eds. Mental retardation: a review of research. Chicago: University of Chicago Press, 1964:429-52.
6. Malamud N. Neuropathology of organic brain syndromes associated with aging. In: Gaitz $\mathrm{CM}$, ed. Aging and the brain. New York: Plenum Press, 1972:63-87.

7. Burger PC, Vogel FS. The development of the pathologic changes of Alzheimer's disease and senile dementia in patients with Down's syndrome. Am J Pathal 1973;73:457-68.

8. Ropper AH, Williams RS. Relationship between plaques, tangles and dementia in Down syndrome. Neurology (NY) 1980;30:639-44.

9. Wisniewski KE, Wisniewski HM, Wen GY. Plaques, tangles and dementia in Down syndrome. Abstract. J Neuropathol Exp Neurol 1983;42:340.

10. Wisniewski KE, Wisniewski HM, Wen GY. Occurrence of neuropathological changes and dementia of Alzheimer's disease in Down's syndrome. Ann Neurol 1985;17:278-82.

11. Liss L, Shim C, Thase M, Smeltzer D, Malton J, Couri D. Relationship between Down syndrome (DS) and dementia Alzheimer type (DAT). Abstract. J Neuropathol Exp Neurol 1980;39:371.

12. Dalton AJ, Crapper McLachlan DR. Incidence of memory deterioration in aging persons with Down's syndrome. In: Berg JM, ed. Perspectives and progress in mental retardation. Biomedical aspects, vol 2. Baltimore: University Park Press, 1984:55-62.

13. Crapper DR, Dalton AJ, Skopitz M, Scott JW, Hachinski V. Alzheimer degeneration in Down syndrome: electrophysiologic alterations and histopathologic findings. Arch Neurol 1975;32:618-23.

14. Crapper DR, Krishnan SS, Quittkat S. Aluminium, neurofibrillary degeneration and Alzheimer's disease. Brain 1976;99:67-80.

15. Dalton AJ, Crapper DR. Down's syndrome and aging of the brain. Technical report No. 13. Toronto, Ontario Ministry of Community and Social Services, February 1977.

16. Dalton AJ, Crapper DR. Down's syndrome and aging of the brain. In: Mittler P, ed. Research to practice in mental retardation. Biomedical aspects, vol 3. Baltimore: University Park Press, 1977:391-400.

17. De Boni U, Dalton AJ, Schlotterer GR, Crapper DR. Senile dementia: recent concepts of pathophysiology. Research in dementia: proceedings of a Colloquium of the Ontario Psychogeriat. Assoc Res Bull, Ontario Psychol 1977;3:1-15.

18. Dalton AJ, Crapper DR, Schlotterer GR. Alzheimer's disease in Down's syndrome: visual retention deficits. Cortex 1974;10:366-77.

19. Wisniewski KE, Hill AL. Clinical aspect of dementia in developmental disabilities. In: Janicki MP, Wisniewski HM, eds. Aging and developmental disabilities: issues and approaches. Baltimore: Paul H. Brookes 1985:195-210.

20. Roth M, Tomlinson BE, Blessed G. Correlations between scores of dementia and counts of senile plaques in cerebral gray matter of elderly subjects. Nature 1966;209:109-10.

21. Sinex FM, Meyers RH. Alzheimer's disease, Down's syndrome and aging: the genetic approach. Ann NY Acad Sci 1982;396:3-13

22. Wisniewski KE, Howe J, Williams DG, Wisniewski HM. Pre cocious aging and dementia in patients with Down's syndrome. Biol Psychiatry 1978;13:619-27.

23. Wisniewski KE, French JH, Rosen JF, Kozlowski PB, Tenner M, Wisniewski HM. Basal ganglia calcification (BGC) in Down's syndrome (DS): another manifestation of premature aging. Ann NY Acad Sci 1982;396:179-89

24. Wisniewski KE, Wisniewski HM. Age associated changes and dementia in Down syndrome. In: Reisberg B, ed. Textbook of Alzheimer's disease and senile dementia. New York: McMillan, 1983:319-25.

25. De Leon MJ, George AE, Ferris SH, et al. Regional correlation of PET and CT in senile dementia of the Alzheimer type. AJNR 1983;4:553-6.

26. Owens D, Dawson JC, Lowson S. Alzheimer's disease in Down's syndrome. Am J Ment Defic 1971;5:606-12.

27. Wisniewski KE, Jervis GA, Moretz RC, Wisniewski HM. Alzheimer's neurofibrillary tangles in diseases other than senile and presenile dementia. Ann Neurol 1979;5:288-94.

28. Rudelli RD, Ambler MW, Wisniewski HM. Morphology and distribution of Alzheimer neuritic (senile) and amyloid plaques in striatum and diencephalon. Acta Neuropathol (Berl) $1984 ; 64: 273-81$

29. Mandybur TI. The incidence of cerebral amyloid angiopathy in Alzheimer's disease. Neurology (Minneap) 1975;25:120-6. 


\title{
Neurology
}

\section{Alzheimer's disease in Down's syndrome: Clinicopathologic studies}

\author{
K. E. Wisniewski, A. J. Dalton, D. R. Crapper McLachlan, et al.
}

Neurology 1985;35;957

DOI 10.1212/WNL.35.7.957

This information is current as of July 1,1985

\section{Updated Information \& \\ Services}

Citations

Permissions \& Licensing

Reprints including high resolution figures, can be found at: http://n.neurology.org/content/35/7/957.full

This article has been cited by 7 HighWire-hosted articles: http://n.neurology.org/content/35/7/957.full\#\#otherarticle

Information about reproducing this article in parts (figures,tables) or in its entirety can be found online at: http://www.neurology.org/about/about_the_journal\#permi ssions

Information about ordering reprints can be found online: http://n.neurology.org/subscribers/advertise

Neurology ${ }^{\circledR}$ is the official journal of the American Academy of Neurology. Published continuously since 1951, it is now a weekly with 48 issues per year. Copyright $@ 1985$ by the American Academy of Neurology. All rights reserved. Print ISSN: 0028-3878. Online ISSN: $1526-632 X$.

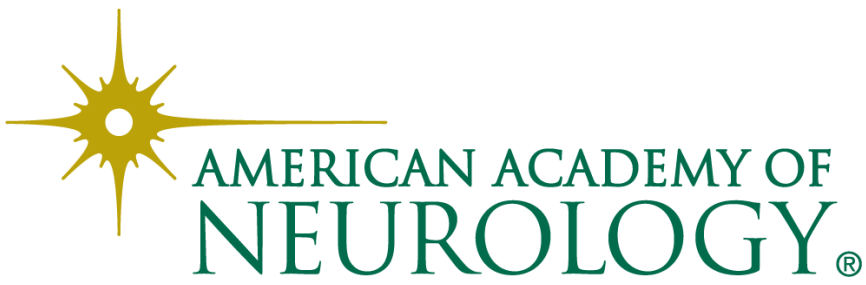

